\title{
EVALUATION OF THE ELISA-F29 TEST AS AN EARLY MARKER OF THERAPEUTIC EFFICACY IN ADULTS WITH CHRONIC CHAGAS DISEASE
}

Diana FABBro(1), Elsa VELAZQUEZ(2*), Maria Laura BIZAI(1) Susana DENNER(1), Verónica OLIVERA(1), Enrique ARIAS(1), Carlos PRAVIA(2) \& Andrés M. RUIZ(2*)

\begin{abstract}
SUMMARY
This work compared the time at which negative seroconversion was detected by conventional serology (CS) and by the ELISA-F29 test on a cohort of chronic chagasic patients treated with nifurtimox or benznidazole. A retrospective study was performed using preserved serum from 66 asymptomatic chagasic adults under clinical supervision, and bi-annual serological examinations over a mean follow-up of 23 years. Twenty nine patients received trypanocide treatment and 37 remained untreated. The ELISA-F29 test used a recombinant antigen which was obtained by expressing the Trypanosoma cruzi flagellar calcium-binding protein gene in Escherichia coli. Among the untreated patients, 36 maintained CS titers. One patient showed a doubtful serology in some check-ups. ELISA-F29 showed constant reactivity in 35 out of 37 patients and was negative for the patient with fluctuating CS. The treated patients were divided into three groups according to the CS titers: in 13 they became negative; in 12 they decreased and in four they remained unchanged. ELISA-F29 was negative for the first two groups. The time at which negativization was detected was significantly lower for the ELISA-F29 test than for CS, $14.5 \pm 5.7$ and $22 \pm 4.9$ years respectively. Negative seroconversion was observed in treated patients only. The results obtained confirm that the ELISA-F29 test is useful as an early indicator of negative seroconversion in treated chronic patients.
\end{abstract}

KEYWORDS: Chagas disease; Trypanosoma cruzi; Chemotherapy; Diagnosis.

\section{INTRODUCTION}

American trypanosomiasis or Chagas disease, caused by the parasite Trypanosoma cruzi, is endemic in 21 countries of Central and South America. The Pan American Health Organization (PAHO) estimates that 7.7 million people currently have $T$. cruzi infection and 50,000 patients die every year due to Chagas disease ${ }^{17}$.

Although the infection is mainly transmitted by vectors, there are other transmission routes such as blood transfusions, organ transplants or through the placenta.

Human Chagas disease begins with an acute phase that appears just after a generally asymptomatic infection or with scarce symptoms. Without treatment, most infected persons evolve to a symptomless chronic period in which they stay for the rest of their life. However, several years after infection about $30 \%$ of these people will present clinical evidence of disease with different degrees of cardiac affection and/or gastrointestinal affection.

Trypanocidal drugs, nifurtimox and benznidazole, are recommended for treatment during both the acute and the early chronic phases (children under 15 years old), and for patients who present a risk of reactivation of the latent infection with T. cruzi due to immunosuppression (patients with AIDS and those receiving post-transplant immunosuppressive drugs, or under oncologic treatment).

Both drugs often have side effects that may be worse in older people. Moreover, the existence of naturally resistant $T$. cruzi strains has been demonstrated in experimental models $\mathrm{s}^{12,16,23}$.

Studies carried out on adult persons with chronic T. cruzi infection have shown great differences in the trypanocidal effectiveness and in the progression towards chronic chagasic cardiopathy (CCC) $)^{3,4,6,8,11,24}$.

The evaluation of etiological treatment of adults with chronic T. cruzi infection presents several difficulties, such as the slow natural evolution of the disease and a lack of parasitological and serological tests that can indicate the efficacy of trypanocidal drugs at an early stage.

Circulating parasites are scarce in the chronic phase. Parasitological tests (xenodiagnosis, hemoculture) are only meaningful when they are positive, indicating a therapeutic failure.

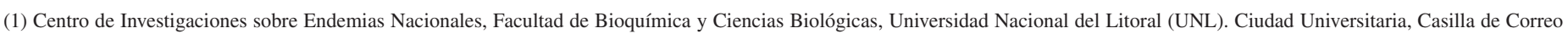
242 (3000) Santa Fe, Argentina. Tel: +54.342.4575207 Int. 152.

(2) Instituto Nacional de Parasitología Dr. Mario Fatala Chaben, Buenos Aires, Argentina. *CONICET.

Correspondence to: Diana L. Fabbro. 25 de Mayo 1524, 3000 Santa Fe. Santa Fe, Argentina. Tel: 54.0342.4595085. E-mail: dfabbro@ fbcb.unl.edu.ar 


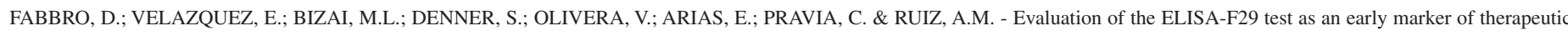
efficacy in adults with chronic Chagas disease. Rev. Inst. Med. Trop. Sao Paulo, 55(3): 167-72, 2013.

Nowadays, conventional serology (CS) is the main tool for the primary diagnosis of this infection in the chronic phase. Therefore, the accepted criterion of cure after treatment is the persistent absence of anti-T. cruzi antibodies as measured by $\mathrm{CS}^{5}$.

The parasites are extremely antigenic and produce a strong antibody response that persists even after complete deparasitation. The progressive decrease in titers usually takes years or decades until serology becomes negative. This diminution occurs more slowly in adults than in children.

Many serological techniques have been evaluated as possible cure markers ${ }^{1,13,14,15}$. Furthermore, there has been an increase in the use of molecular methods for detecting T. cruzi in blood samples of treated patients $^{4,7,19,20}$.

During the 1990s, two randomized clinical trials in children with chronic T. cruzi infection treated with benznidazole were performed using non-conventional serological methods (AT ELISA and ELISA-F29) as cure markers. The results showed the safety and efficacy of this drug, as it produced negative seroconversion in $55.8 \%$ and $62 \%$ of the patients, three and four years after treatment respectively ${ }^{2,21}$. Our group performed a longitudinal study in chronic chagasic children younger than 14 years of age treated with nifurtimox or benznidazole. Although it is difficult to compare the results from different methods, we observed a similar percentage of negativization according to CS, but after a follow-up period of 14 years ${ }^{22}$.

On the other hand, we previously reported the results of a transversal study performed on sera from chronic chagasic patients treated with nifurtimox or benznidazole, which sought to evaluate the recombinant protein F29 as a possible marker of treatment efficacy. There was a correlation between CS and ELISA-F29 for treated patients who showed negativization in CS and for non-treated patients, but no treated patients remained reactive to $\mathrm{CS}^{9}$.

The aim of the present work was to compare the time at which negative seroconversion is detected in both tests, ELISA-F29 and CS, in a cohort of adult patients with chronic $T$. cruzi infection both treated and untreated (control group) with trypanocidal drugs.

\section{MATERIALS AND METHODS}

This retrospective study was carried out on 66 adult patients with chronic infection by $T$. cruzi who were voluntarily attending the Centre for Research in National Endemic Diseases for check-ups, during a mean follow-up of 23 years. The Centre is located within the School of Biochemical Sciences, Littoral National University, Santa Fe City, Argentina.

The participants were selected according to their current residence (Santa Fe City, Argentina) and age (17 to 46 years old). They were informed about the study and those who gave their consent to participate in it were included in the follow-up. This protocol was approved by the Ethics Committee of the School of Biochemistry and Biological Sciences.

Patients were controlled every two years by means of clinical examination, 12-lead resting electrocardiogram (ECG) and serological studies of venous blood samples.
CS tests included direct agglutination (DA), indirect hemagglutination (IHA), indirect immunofluorescence (IIF) and ELISA, with whole homogenate of T. cruzi. Sera with positive reactions to all tests were considered positive ( $\geq 1 / 32$ titers for the first three reactions). Serum samples obtained from the different serological check-ups were preserved at $-20{ }^{\circ} \mathrm{C}$ and/or glycerinated.

The criterion for negative seroconversion was the persistent negativization of all previously positive tests. A "decrease in serum titers" was considered when the number dropped in two or more dilutions of serum without reaching negative seroconversion, "inconclusive serology" when some tests were reactive to 1/32 titers and others were non-reactive, and finally "fluctuating serology" when CS tests showed reactivity in some serological checks and not in others.

Before 1983 trypanocide treatment was administered to symptomless infected individuals who had given their consent to be treated. Depending on the availability of drugs, patients were given nifurtimox $(8-10 \mathrm{mg} /$ $\mathrm{kg} /$ day over $45-60$ days) or benznidazole $(5 \mathrm{mg} / \mathrm{kg} /$ day over 30 days, with half of the dose in the first week). None of the cases were pregnant women or patients with associated severe diseases (systemic infections with cardiac, respiratory, renal or hepatic insufficiency). Procedures were in accordance with the ethical standards of the National Ministry of Health, Argentina.

Chosen individuals $(n=66)$ were those who attended regularly for controls with well preserved serum samples. Twenty nine symptomless patients received trypanocide treatment (nifurtimox $=16$; benznidazole $=13$ ) and 37 remained untreated.

F29 Antigen: The F29 gene (GenBank accession number: Z54193.1) was originally cloned into the pMalp $2 \mathrm{X}$ expression vector ${ }^{18}$. In order to increase the amount of expressed protein and to avoid the cleavage step of the fusion protein, the F29 gene was subcloned into the pQE32 vector. The gene was amplified using the forward primer F29 (5'-ATG GGT GCT TGT GGG TCG AA-3 ') and the reverse primer F29 (5'-TCA AGC CTT CTC CGG CAC GT -3'). The PCR reaction was performed using $P f u$ polymerase, and finally the amplified fragment was cloned into the Sma I site of expression vector pQE32 (Qiagen). The 6 His - F29 protein was expressed and purified using a column of nickel-nitrilotriacetic acid agarose (Qiagen) under native conditions following the manufacturer's protocol.

ELISA-F29: An ELISA test using the F29 protein of T. cruzi was performed on 211 serums collected at different times during the followup of 66 patients, distributed as follows: A) 108 samples belonged to 29 patients treated with trypanocidal drugs. Only five of them had serum samples before the specific treatment. For the rest, the lack of available samples in a good state of conservation was no reason to exclude patients, due to the limited number of infected persons undergoing treatment. For nine patients the first sample analyzed was taken between one and four years post-treatment; for the remaining 15 , the first analysis was carried out on sera that had been collected at a mean time of 11 years after the treatment had finished, B) 103 serum from 37 untreated patients.

The conservation status of sera was previously evaluated through CS. Those sera that preserved the antibody level observed in fresh serum at the moment of serological check-up were selected. 


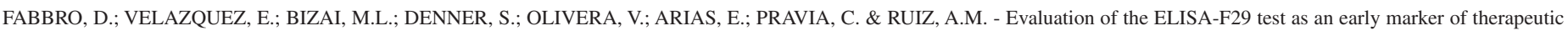
efficacy in adults with chronic Chagas disease. Rev. Inst. Med. Trop. Sao Paulo, 55(3): 167-72, 2013.

Table 1

Patients with chronic Chagas disease, treated with trypanocidal drugs and untreated, distributed according to age groups, sex and length of follow-up

\begin{tabular}{|c|c|c|c|c|c|c|}
\hline \multirow{2}{*}{$\begin{array}{l}\text { Age }^{\S} \text { group } \\
\text { (years) }\end{array}$} & \multicolumn{3}{|c|}{ Treated } & \multicolumn{3}{|c|}{ Untreated } \\
\hline & Sex F/M & Total & $\begin{array}{l}\text { Years of follow-up } \\
\quad(\text { mean } \pm \text { SD })\end{array}$ & Sex F/M & Total & $\begin{array}{l}\text { Years of follow-up } \\
\quad(\text { mean } \pm \text { SD })\end{array}$ \\
\hline 17 to 26 & $5 / 3^{a}$ & 8 & $23.6 \pm 3.8^{b}$ & $8 / 4^{a}$ & 12 & $23.3 \pm 5.7^{b}$ \\
\hline 27 to 36 & $12 / 3^{a}$ & 15 & $22.2 \pm 3.0^{b}$ & $13 / 4^{a}$ & 17 & $23.6 \pm 2.5^{b}$ \\
\hline 37 to 46 & $5 / 1^{a}$ & 6 & $21.3 \pm 5.6^{b}$ & $5 / 3^{a}$ & 8 & $22.9 \pm 4.2^{b}$ \\
\hline Total & $22 / 7$ & 29 & & $26 / 11$ & 37 & \\
\hline
\end{tabular}

$\S$ Age at the time of inclusion; $a$ : the proportion of men and women was similar between treated and untreated patients, $p>0.05$ binomial test; $b$ : there were no significant differences in the length of follow-up between treated and untreated patients, $p>0.05$ Student's test.

\section{Cut-off value ELISA-F29 $=0.198$}

Statistical analysis: Student's t-test, Mann Whitney U test, binomial test, Kaplan-Meier curves, log-rank test and GEE (Generalized Estimating Equations) were used as was appropriate. A $p$ value of $<0.05$ was considered significant.

\section{RESULTS}

The people in both groups of patients infected with T. cruzi, those treated with trypanocidal drugs and those who remained untreated, were of similar age, sex and follow-up period (Table 1).

Treated patients $(n=29)$ were grouped according to the serological evolution of CS during the follow-up as follows: (i) 13 had negative seroconversion; (ii) 12 presented a significant decrease of titers or inconclusive serology, while (iii) four remained reactive and conserved the serological titers.

Table 2 shows the results of ELISA-F29 during the follow-up, in relation to the serological evolution of CS in the treated patients.

Table 2

Serological evolution of CS and ELISA-F29 for the group of treated patients

\begin{tabular}{lcccc}
\hline & \multicolumn{3}{c}{ ELISA-F29 } & \\
\cline { 2 - 4 } CS & Constant (-) & $\begin{array}{l}\text { Negative se- } \\
\text { roconversion }\end{array}$ & Constant (+) & \\
\hline $\begin{array}{l}\text { i - Negative } \\
\text { seroconver- } \\
\text { sion }\end{array}$ & 5 & 8 & 0 & 13 \\
$\begin{array}{l}\text { ii - Decreased } \\
\text { titres or } \\
\text { inconclusive }\end{array}$ & 4 & 8 & 0 & 12 \\
$\begin{array}{l}\text { serology } \\
\text { iii - Constant } \\
\text { titres (+) }\end{array}$ & 1 & 1 & 2 & \\
\hline Total & 10 & 17 & 2 & 4 \\
\hline
\end{tabular}

CS: conventional serology.
As can be seen in the table, final reactivity of the ELISA-F29 test was observed in $2 / 29(6.9 \%)$ of the patients undergoing specific treatment. In 10/29 patients the ELISA-F29 test did not detect Ac anti-F29, all the analyzed samples being post-treatment. Negative seroconversion according to the ELISA-F29 test was observed in 17/19 (89.4\%) of infected patients treated, while according to CS this happened only in $13 / 29(44.8 \%)$ of them. These proportions differ significantly $(p<0.05$, binomial test).

Because of the conservation status of sera, pre-treatment samples were not available from all patients. In fact, the first sample analyzed corresponded to a different time for each one of the patients, both before and after treatment.

The relationship between the time when the first available sample was analyzed and the reactivity of ELISA-F29 is detailed in Table 3. As the time elapsed since the completion treatment increased, the reactivity of the sample decreased $(p<0.05$, binomial test).

Table 3

Percentage of positivity of ELISA-F29 on the first sample analyzed according to the time that passed since finalizing the treatment

\begin{tabular}{lccc}
\hline \multirow{2}{*}{$\begin{array}{l}\text { Time of the first sample } \\
\text { analyzed }\end{array}$} & $\mathrm{n}$ & Positivity & $\%$ \\
\cline { 2 - 4 } & 5 & 5 & 100 \\
\hline $\begin{array}{l}\text { Pre-treatment } \\
\text { Post-treatment }\end{array}$ & & & \\
$\quad \leq 4$ years & 9 & 7 & 77.7 \\
$\quad>4$ years & 15 & 5 & 33.3 \\
\hline
\end{tabular}

$p<0.05$, binomial test.

Using the GEE model, which includes all measurements of anti-F29 antibodies from each patient during the follow-up, a significant fall of these antibodies due to treatment was observed $(p<<0.05$; measure of OD drop $=0.177$ ).

The average time for negative seroconversion was $14.5 \pm 5.7$ years for ELISA-F29 and $22 \pm 4.9$ years for CS. These differences were statistically significant ( $p=0.0004$, Student's t-test). 
FABBRO, D.; VELAZQUEZ, E.; BIZAI, M.L.; DENNER, S.; OLIVERA, V.; ARIAS, E.; PRAVIA, C. \& RUIZ, A.M. - Evaluation of the ELISA-F29 test as an early marker of therapeutic efficacy in adults with chronic Chagas disease. Rev. Inst. Med. Trop. Sao Paulo, 55(3): 167-72, 2013.

The probability of negative seroconversion (proportion of reactive patients during the follow-up) according to CS or ELISA-F29 was evaluated using the Kaplan-Meier curves (Fig. 1).

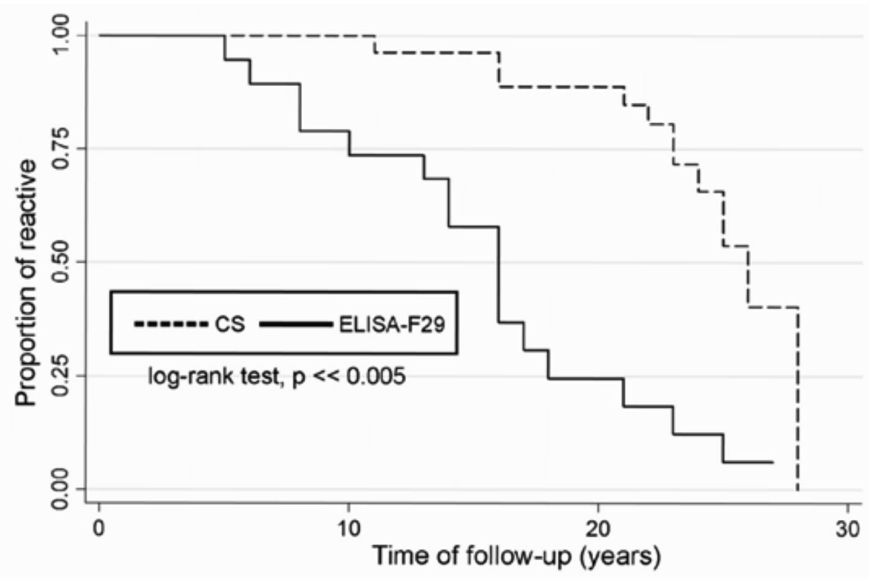

Fig. 1 - Kaplan Meier curve demonstrating the proportion of reactivity over time by CS and ELISA-F29 in treated chronic chagasic patients.

When using the log-rank test for comparing both curves, a very significant difference $(p<<0.05)$ was observed.

$50 \%$ of treated patients presented negativization 16 years after treatment, according to the ELISA-F29 test, while according to CS this happened 26 years post-treatment.

The age of the patients at the time at which they received trypanocide treatment was considered. The relation between the age at which infected patients were treated and the probability of negative seroconversion according to CS and ELISA-F29 was not statistically relevant among the three age groups $(p>0.05, \log$-rank test).

No significant differences were observed when the probability of negative seroconversion according to CS was analyzed with respect to the drug used in the treatment - nifurtimox or benznidazole- $(p=0.73)$. The same thing happened for the ELISA-F29 test $(p=0.59)$.

Among the untreated patients $(n=37)$, the initial CS titers remained constant during the follow-up in 36 of them and only one presented fluctuating serology in some check-ups.

The ELISA-F29 test was reactive in $94.6 \%$ (35/37) of them; no changes in reactivity were seen throughout the follow-up. No F29 antibodies were detected in the only patient whose CS fluctuated.

In the untreated patients group, no negative seroconversion was observed in any of the tests (CS and ELISA-F29).

\section{DISCUSSION}

In previous publications ${ }^{10,11}$ our group showed results of an evaluation of a specific antiparasitic treatment in adults with chronic infection by Trypanosoma cruzi, with an average follow-up of 23 years.
Before treatment, $94.7 \%$ of the patients had positive xenodiagnosis. Post-treatment, three xenodiagnoses per patient were performed, all of which were negative.

Accompanying these results, persistent negative seroconversion according to CS in at least $45.5 \%$ of patients treated with nifurtimox or benznidazole was observed. The average time of serological negativization was 19 years post-treatment.

With regard to clinical evolution, $3.64 \%$ of the treated patients and $17.54 \%$ of the untreated ones showed disturbances on electrocardiograms during the follow-up period, attributable to Chagas disease. This difference is statistically significant $(p<0.05)$.

These results coincide with those of other researchers who have used the same doses and period for benznidazole administration $(5 \mathrm{mg} /$ $\mathrm{kg} /$ day over 30 days $)^{24,25}$.

These studies demonstrate the effectiveness of the trypanocidal treatment after a period of 15 years. The required prolonged time of follow-up constitutes the main difficulty for the therapeutic evaluation in infected chronic patients. In the present work the times at which negative seroconversion was detected by ELISA-F29 were significantly smaller than the ones observed for CS.

The percentage of treated patients who did not present reactivity for ELISA-F29 was high. It is important to highlight that the majority of the serum samples analyzed were collected after treatment because of the conservation status. Pre-treatment samples $(n=5)$ in good condition for analysis were $100 \%$ positive.

In the group of nontreated patients, $94.6 \%$ of them were persistently positive for the ELISA-F29 test. It is expected that a similar percentage of reactivity occurs in serum samples obtained before the therapeutic intervention.

Furthermore, the anti-F29 antibody evolution significantly decreased due to the effect of the treatment when all sera belonging to each patient were analyzed, with a DO decrease of 0.177 among samples. This decrease is close to the cut-off value (0.198).

Despite limitations of sensitivity that are frequently present in recombinant techniques that use $\mathrm{Ag}$ of a single band, only negative seroconversion was observed in the patients that received treatment, which together with the fall in the level of anti-F29 reactivity would indicate a diminution of the parasitic load at least.

In the final follow-up, the reactivity of the ELISA-F29 test to sera from treated patients was $6.9 \%$. This finding led us to presume that the treatment was able to eliminate all parasites in $93.1 \%$ of infected individuals.

It is necessary to continue with the follow-up of patients whose CS is positive and ELISA-F29 negative, in order to corroborate this presumption.

The results of the ELISA-F29 test for untreated patients showed no negative seroconversion for anyone in this group. As for the patients 
FABBRO, D.; VELAZQUEZ, E.; BIZAI, M.L.; DENNER, S.; OLIVERA, V.; ARIAS, E.; PRAVIA, C. \& RUIZ, A.M. - Evaluation of the ELISA-F29 test as an early marker of therapeutic efficacy in adults with chronic Chagas disease. Rev. Inst. Med. Trop. Sao Paulo, 55(3): 167-72, 2013.

who did not present anti-F29 antibodies (2/37), it is necessary to carry out complementary studies such as the Western blot analysis and PCR, in order to define this discrepancy.

The probability of negative seroconversion according to CS and ELISA-F29 had no connection with the age at which infected adults received treatment. These findings are different to those observed in children with chronic infection, since the lower the age of the treated patients, the higher the probability of negativization ${ }^{22}$.

This paper presents the advantage of using serum samples collected at different periods of time over long term supervision. This situation allowed for the observance of the persistent negativization of CS tests, which is the gold standard for cure. When ELISA-F29 and CS tests were evaluated in parallel, the mean time for negative seroconversion was significantly different ( $p<<0.05, \log$-rank test).

In conclusion, our results demonstrate that the ELISA-F29 test significantly anticipated negative seroconversion compared to CS. Consequently, the ELISA-F29 test can be used as a complementary test in the therapeutic evaluation.

The ELISA-F29 test has the advantage of not requiring much infrastructure, since it is a fast serological test with a simple procedure.

\section{RESUMO}

\section{Avaliação do tratamento tripanossomicida em coorte de adultos chagásicos crônicos através de técnicas sorológicas convencionais e ELISA-F29}

Este trabalho comparou os tempos de soroconversão negativos obtidos pela sorologia convencional (CS) e teste ELISA-F29 em uma coorte de pacientes chagásicos crônicos tratados com nifurtimox ou benznidazol. Um estudo retrospectivo foi realizado com soro preservado de 66 adultos chagásicos assintomáticos com acompanhamento clínico e sorológico semestral ao longo de um seguimento médio de 23 anos. 29 pacientes receberam tratamento tripanossomicida e 37 outras permaneceram sem tratamento. O teste ELISA-F29 usou um antígeno recombinante obtido por expressão do gene de uma proteína flagelar de Trypanosoma cruzi de ligação de cálcio em Escherichia coli. Entre os pacientes não tratados, 36 mantiveram os títulos da CS. Um paciente apresentou sorologia duvidosa em alguns controles. ELISA-F29 apresentou reatividade constante em $35 / 37$ e foi negativo no paciente com CS flutuante. Os pacientes tratados foram agrupados de acordo com os títulos da CS, em três grupos: 13 tornaram-se negativos, 12 diminuíram e quatro permaneceram inalterados. ELISA-F29 foi negativo nos dois primeiros grupos. O tempo de negativização foi significativamente menor para o teste ELISA-F29 do que para CS $(14,5 \pm 5,7$ e $22 \pm 4,9$ anos, respectivamente). A soroconversão negativa foi observada somente nos pacientes tratados. Os resultados obtidos confirmam que o teste ELISA-F29 é útil como um indicador precoce de soronegativação em pacientes crônicos tratados.

\section{ACKNOWLEDGEMENTS}

Financial support: The study was supported by the Secretaría de Ciencia y Tecnología de la Universidad Nacional del Litoral and INP/ ANLIS, Ministerio de Salud de la Nación, Argentina.

\section{REFERENCES}

1. Altcheh J, Corral R, Biancardi MA, Freilij H. Anticuerpos anti-F2/3 como marcador de curación en niños con infección congénita por Trypanosoma cruzi. Medicina (B Aires). 2003;63:37-40.

2. Andrade ALSS, Zicker F, Oliveira RM, Silva SS, Luquetti A, Travassos LR, et al. Randomised trial of efficacy of benznidazole in treatment of early Trypanosoma cruzi infection. Lancet. 1996;348:1407-13.

3. Braga MS, Lauría Pires L, Argañaraz E, Nascimento RJ, Teixeira A. Persistent infections in chronic Chagas' disease patients treated with anti-Trypanosoma cruzi nitroderivatives. Rev Inst Med Trop Sao Paulo. 2000;42:157-61.

4. Britto C, Silveira C, Cardoso MA, Marques P, Luquetti A, Macedo V, et al. Parasite persistence in treated chagasic patients revealed by xenodiagnosis and polymerase chain reaction. Mem Inst Oswaldo Cruz. 2001;96:823-6.

5. Cançado JR. Criteria of Chagas disease cure. Mem Inst Oswaldo Cruz. 1999;94(Suppl):331-5.

6. Cançado JR. Long term evaluation of etiological treatment of Chagas disease with benznidazole. Rev Inst Med Trop Sao Paulo. 2002;44:29-37.

7. Carvalho Britto C. Usefulness of PCR-based assays to assess drug efficacy in Chagas disease chemotherapy: value and limitations. Mem Inst Oswaldo Cruz. 2009;104(Suppl 1):122-35.

8. Cerisola JA. Chemotherapy of Chagas infections in man. Scientific Publication PAHO 1977;347:35-47.

9. Fabbro D, Velázquez E, Mendoza N, Streiger M, Arias E, Denner S, et al. Evaluación de ELISA F29 como marcador de eficacia en el tratamiento etiológico de la enfermedad de Chagas. Parasitol Latinoam. 2007;62:103-11.

10. Fabbro D, Bizai ML, Streiger M, del Barco M, Amicone N, Arias E. Confirman la utilidad de la quimioterapia específica en la enfermedad de Chagas crónica. Salud(i)Cienc. 2010;17:786-8.

11. Fabbro D, Streiger ML, Arias ED, Bizai ML, del Barco M, Amicone NA. Trypanocide treatment among adults with chronic Chagas disease living in Santa Fe city (Argentina) over a mean follow-up of 21 years: pasitological, serological and clinical evolution. Rev Soc Bras Med Trop. 2007;40:1-10.

12. Filardi LS, Brener Z. Susceptibity and natural resistance of Trypanosoma cruzi strains to drugs used clinically in Chagas disease. Trans R Soc Trop Med Hyg. 1987;81:755-9.

13. Krautz GM, Galvao LMC, Cancado JR, Guevara-Espinoza A, Ouaisse A, Krettli A. Use of a 24-kilodalton Trypanosoma cruzi recombinant protein to monitor cure of human Chagas' disease. J Clin Microbiol. 1995;33:2086-90.

14. Krettli AU. The utility of anti-trypomastigote lytic antibodies for determining cure of Trypanosoma cruzi infections in treated patients: an overview and perspectives. Mem Inst Oswaldo Cruz. 2009;104(Suppl 1):142-51

15. Martins-Filho AO, Eloi-Santos SM, Carvalho AT, Oliveira RC, Rassi A, Luquetti AO, et al. Double-blind study to evaluate flow cytometry analysis of anti-live trypomastigote antibodies for monitoring treatment efficacy in cases of human Chagas disease. Clin Diagn Lab Immunol. 2002;9:1107-13

16. Neal RA, van Bueren J. Comparative studies of drug susceptibility of five strains of Trypanosoma cruzi in vivo and in vitro. Trans R Soc Trop Med Hyg. 1988;82:709-14

17. PAHO/WHO. Estimación cuantitativa de la enfermedad de Chagas en las Américas. Washington: OPS/HDM/CD/425-06; 2006. p. 6.

18. Porcel BM, Bontempi EJ, Henriksson J, Rydaker M, Åslund E, Segura EL, et al. Trypanosoma rangeli and Trypanosoma cruzi: molecular characterization of genes encoding putative calcium-binding proteins, highly conserved in trypanosomatids Exp Parasitol. 1996;84:387-99. 
FABBRO, D.; VELAZQUEZ, E.; BIZAI, M.L.; DENNER, S.; OLIVERA, V.; ARIAS, E.; PRAVIA, C. \& RUIZ, A.M. - Evaluation of the ELISA-F29 test as an early marker of therapeutic efficacy in adults with chronic Chagas disease. Rev. Inst. Med. Trop. Sao Paulo, 55(3): 167-72, 2013.

19. Schijman AG, Altcheh J, Burgos JM, Biancardi M, Bisio M, Levin MJ, et al. Aetiological treatment of congenital Chagas disease diagnosed and monitored by the polymerase chain reaction. J Antimicrob Chemother. 2003;52:441-9.

20. Solari A, Ortiz S, Soto A, Arancibia C, Campillay R, Contreras M, et al. Treatment of Trypanosoma cruzi-infected children with nifurtimox: a 3 year follow-up by PCR. J Antimicrob Chemother. 2001;48:515-9.

21. Sosa-Estani S, Segura EL, Ruiz AM, Velazquez E, Porcel BM, Yampotis C. Efficacy of chemoterapy with benznidazole in children in the indeterminate phase of Chagas'disease. Am J Trop Med Hyg. 1998;59:526-9.

22. Streiger ML, del Barco ML, Fabbro DL, Arias ED, Amicone NA. Estudo longitudinal e quimioterapia específica em crianças, com doença de Chagas crônica, residentes em área de baixa endemicidade da República Argentina. Rev Soc Bras Med Trop. 2004;37:365-75.
23. Veloso VM, Carneiro CM, Toledo MJO, Lana M, Chiari E, Tafuri WI, et al. Variation in susceptibility to benznidazole in isolates derived from Trypanosoma cruzi parental strains. Mem Inst Oswaldo Cruz. 2001;96:1005-11.

24. Viotti R, Vigliano C, Armenti H, Segura E. Treatment of chronic Chagas' disease with benznidazole: clinical and serologic evolution of patients with long-term follow-up. Am Heart J. 1994;127:151-62.

25. Viotti RJ, Vigliano C, Lococo B, Bertocchi G, Petti M, Alvarez MG, et al. Long-term cardiac outcomes of treating chronic Chagas disease with benznidazole versus no treatment: a nonrandomized trial. Ann Intern Med. 2006;144:724-34.

Received: 22 December 2011

Accepted: 3 December 2012 